\title{
Exploring the Science of Marma - An Ancient Healing Technique - Part 4: Marma Therapy
}

\author{
Alka Mishra*, Vandana Shrivastava \\ Department of Ayurveda and Holistic Health, Dev Sanskriti Vishwavidyalaya, \\ Gayatrikunj-Shantikunj, Haridwar, Uttarakhand, India
}

*Corresponding Author: Alka Mishra - Email: alka.mishra@dsvv.ac.in

\section{License information for readers:}

This paper is published online under the Creative Commons Attribution (CC BY 4.0) License, whose full terms may be seen at https://creativecommons.org/licenses/by/4.0/

Uploaded online: 1 July 2020

\begin{abstract}
Marma Science, an extraordinary gem in the vast treasure of Ayurvedic knowledge, represents the science of specific vital places in the body (Marmas), that are the 'seats of life' (Prana - the vital life force). As any injury to these parts may lead to severe pain, disability, loss of function, loss of sensation, or death, therefore, they hold an important place in the science of surgery. The ancient scriptures have strictly prohibited causing any injury to the Marmas. However, recent researches have used Marma stimulation for theraputic benefits, with encouraging outcomes. Looking at these mutually conflicting, important applications of Marma Science, the present study was undertaken for its in-depth analysis.

Part-1 of this study explored different aspects of Marma Science in ancient / classical Indian scriptures. Part-2 gave detailed description of the number of Marmas, their location, structures involved, classification, effect of trauma, etc., as per classical texts, as well as correlation with modern science. Part-3 explored its use in Yoga and other ancient Indian traditions, both as a therapeutic technique, as well as for self defense and inflicting injury on the opponents.

The present article explored its application as a therapeutic procedure (Marma Therapy). Different methods of Marma stimulation have been compiled. Theraputic classification and applications of Marmas have been listed, and several research studies on Marma Therapy have been presented. Several mechanisms for the mode of action of Marma Therapy have been discussed. It is concluded that Marma Science holds significant promise as an effective therapeutic procedure.
\end{abstract}

Keywords: Ayurveda, Marma Science, Marma Therapy, Marma Mechanism, Yoga, Kalaripayat, Varma-kalai 


\section{Introduction}

Marma Science is one of the extraordinary gems in the huge treasure of Ayurvedic knowledge $[1,2]$. It represents the science of specific vital places in the body (Marmas), that are the 'seats of life' (Prana) (Ashtanga Hridaya Sharira Sthana 4/2) [2] (Prana is the vital life force that governs all the physical and subtle processes of a living being [3-6]). As any injury to these parts may lead to severe pain, disability, loss of function, loss of sensation, or death [7], therefore, they hold an important place in the science of surgery, wherein they are considered 'Shalya Vishayardha' (half of the entire science of surgery) (Sushruta Samhita Sharira Sthana 6/35) [1]. Acharya Sushruta states that Marma sthan, a very vital point, should not be injured and should be kept intact even while doing surgeries (Sushruta Samhita Sharira Sthana 6/21) [1].

However, recent researches indicate that if any Marma point is inflamed or painful, then stimulating its nearby Marma points can help in alleviating this pain [8]. Several studies and texts have reported the benefits of Marma Therapy in treating various physical and mental disorders [7-30].

Looking at the importance of the Marma Science with regards to surgeries, as well as their recent use and future possibilities as an effective therapeutic procedure, the present study has been undertaken for an in-depth study of the Science of Marma.

An account of various ancient / classical Indian scriptures, including the Vedas, Upanishads, Puranas, Samhitas, etc., that mention different aspects of the Science of Marma [1,2,7-15,26-45], was given in Part-1 of this study [46]. Part-2 of this study [47] gave the definition and a detailed description of the properties of Marmas, as stated in the classical texts, mostly written during Samhita kala. The description included information about the number of marmas, their location, structures involved, correlation with Panchamahabhutas, classification, as well as a detailed explanation of marmaghata or viddha lakshanas, i.e. the effect of trauma on Marmas. The anatomical correlation with modern science was also presented. Part-3 of this study [48] dealt with the use of Marma Science in Yoga and other ancient Indian traditions. The correlation between Marma Science and Yogic Science, including the different limbs of Ashtanga Yoga, was presented. Its use in various ancient Indian traditions, both as a martial art for self defense and inflicting injury on the opponents, and as a therapeutic technique for healing purposes, was also illustrated.

The present article, which is Part- 4 of this article series, explores the foundational elements of the Science of Marma with regards to its use as a therapeutic procedure (Marma Therapy), as well as the recent applications of this healing method.

\section{Using Marma Science as a Therapeutic Procedure}

The use of Marma Science as a therapeutic procedure has been observed in some ancient Indian traditions and practices. As described in Part-3 [48] of this article series, Yogasanas, Pranayama, Yogic Bandhas, etc. stimulate the Marma points of the body resulting in the desired therapeutic benefits. Shandilyopanishada (8/2) [49] and Vashishtha Samhita (3/61-64) [50] state that one of the best forms of Pratyahara is the one done by focusing on eighteen specific Marma locations in the body. The knowledge of Marman is employed in various ancient Indian traditional practices like Kalaripayat of Kerala [16,20,28,51], Varma-kalai of Tamil Nadu [20,29,52-54], and Ayurvedic Abhyanga (massage) for therapeutic benefits $[11,18,19,28]$. Thus, Marma Science can be regarded as one of the important healing system of ancient times. Looking at these and similar other instances about the healing ability of Marma points, in modern times, several studies and texts [7-30] have described Marma Science as a therapeutic technique. The present article reviews the work of several such studies in this regard.

With regards to the physical body, Marma points are defined as anatomical sites where muscles, veins, ligaments, bones and joints meet together (Sushruta Samhita Sharira Sthana 6/16) [1]. However, Schrott et al. (2016) [13] state that besides the physical structure, Marma points also represent the junction of mind, body and consciousness; thus, the Marma points may hold vital information with regards to thoughts, emotions and feelings, and their link with the overall health. Schrott et al. (2016) [13] state that stimulation of Marma points can affect the functioning of the internal organs and mind-body coordination, cause healing with regards to improvement in eye-sight, digestive system, headaches, stress, etc.; Marma Therapy can be used to detoxify, revitalize and provide strength to the body. The knowledge of Marman is employed by the practitioners of 
Kalaripayat (ancient Indian Martial Art tradition of Kerala) as a health promoting technique [16,20]. Varma-kalai (branch of Siddha medicine) is an ancient therapeutic technique practiced in Tamil Nadu, that deals with the stimulation of Varmam (the vital spots of the body) for therapeutic benefits [20,5254]. Marma points are stimulated during Abhyanga (massage), either by applying pressure in different ways, or through specific movement of hands or other body parts, for therapeutic benefits $[11,18,19]$.

Joshi (2010) [7] states that Marma Science is one of the oldest medical science for prevention and cure of diseases, promotion of health and calmness of mind, as well as development of selfhealing capabilities. It is extremely effective and acts very rapidly, yet, because of the fact that improper intervention at the Marma sites can even be fatal, its use as a therapeutic procedure, by directly stimulating or affecting the Marma points, was not very common [7], and was limited to some specific traditions and practices. He [7] further defines Marma Therapy as a natural, non-invasive, instant and permanent method of healing. He [7-10] has developed a simple methodology of stimulating the Marma points, and has successfully used this technique for providing relief in chronic disorders like scoliosis, cervical spondylosis, muscular dystrophy, prolapse inter vertebral disc, etc. Pathak (2015) [21] used this technique for the treatment of cervical spondylosis, and observed significant therapeutic benefits. Since more than five years, this simplified form of Marma Therapy has also been administered at Dev Sanskriti Vishwavidyalaya (DSVV), Haridwar, to many patients suffering from osteoarthritis, lumbar spondylosis, cervical spondylosis, sciatica, prolapsed inter vertebral disc, leucodystrophy, etc., with encouraging results. The National Health Portal of India [28] describes Marma Therapy as an important Ayurvedic treatment, wherein the pressure applied on the Marmas causes the vital energy (Prana) to flow along subtle channels (Nadis); this portal mentions the application of Marma Therapy for the management of several diseases, which include paralysis, sciatic pain, migraine, tremors, diabetic neuropathy, trigeminal neuralgia, facial or Bell's palsy, lumbar spondilitis, cervical spondilitis, frozen shoulder, carpal tunnel syndrome, muscular and joint pain, etc.

Just like electric switches, which when turned on, allow the flow of electricity through an equipment and make it work, Marma points may be regarded as special switches in the body, which when properly stimulated, can lead to the proper flow of Prana in different body parts, resulting in the desired therapeutic benefits. Thus, the application of Marma Science as a therapeutic technique (Marma Therapy) can be supposed to be comprising of two basic tasks, i.e.:

- Proper identification of these locations, i.e. specific Marma points - this has already been described in Parts 2 [47] of this study

- Devising methods of stimulating and affecting the Marma points to attain the desired healing effect.

\section{Different Methods of Stimulating and Affecting the Marmas}

Marmas are the seats of Prana (vital life force), i.e. the subtle energy centers where the Prana resides and flows [2]; Prana is the vital life force that governs all the physical and subtle processes of a living being [3-6]. Thus, the stimulation of these centers implies stimulating the flow of Prana, rather than some physical organs or tissues [11]. Since the Prana signifies live electricity flowing through the body, hence the Prana of the therapist is bound to interact with that of the subject [3-6]; thus, the exact location of the Marmas should depend upon the Prana of both the therapist and the subject, and may not be simply a fixed physical site [11]. Therefore, the identification of Marmas may not be a simple physiological definition, but instead a matter of long-term practice and concentration; this may be one of the reasons for the slight variations in the methods of Marma Therapy adopted by different practitioners [11].

Different methods of stimulating and affecting the Marma points, to gain therapeutic benefits, are available in the literature.

Lad and Durve (2015) [12] have described 10 methods of stimulating the Marmas (Techniques of Marma Chikitsa), which include oleation, sudation, dry massage, deep pressure, application of paste and heat, puncturing with a needle, etc.

Frawley et al. (2015) [11] have described several methods of Marma Therapy, which may be classified into three main groups, i.e. (i) massage and energy methods, which include techniques like Abhyanga (massage), applying aromatic oils, applying pressure, etc., (ii) herbal methods, which include application of herbal paste, taking medicinal herbs, etc., (iii) using instruments, which include 
Acupuncture, heat application, etc.

Schrott et al. (2016) [13] explain 20 methods to treat the Marmas, which include techniques like massage, pouring oil, application of herbal paste or heat or light, taking herbal medicines, using aromatic oils, yagya, yogasanas, pranayama, meditation, etc.

Joshi (2010) [7] has been working on Marma stimulation with a very simple method of giving pressure on these points; the rate of applying pressure is in accordance with the heart beat and respiratory rate. This technique depends upon three basic things -

1. Identification of Marma point

2. Giving proper pressure on Marma point with the help of thumb and fingers

3. Relaxation of Marma point

Thus, it may be understood that different methods can be adopted to stimulate and affect the marma points.

\section{Classification of Marmas According to their Therapeutic Use}

Several scholars have given therapeutic classification of Marmas, which is as follows [14]:

I. Sthula (physical) and Sookshma (subtle)

II. Vulnerable (lethal) and Less vulnerable (therapeutic)

III. External and Internal

\section{I. a) Sthula}

The locations and anatomical structure of various marmani are included here. These marmani can be assessed by naked eyes, i.e. Pratyaksha darshana.

\section{b) Sookshma}

Here, various subtle physiological functions are included, which are known and understood through Apta vachana (words of Sages / Rishis) and Anumana pramana (i.e. literature, clinical assumptions, and teachings of experts).

\section{II. a) Vulnerable (Lethal)}

This includes marmani that are fatal, if stimulated in the wrong manner; therefore, one should be extremely cautious while dealing with these. Wrong stimulation of these points can lead to severe injury, unconsciousness or even death [11]. These include Sadya pranahara marma, and neck marmani.

\section{b) Less vulnerable (Therapeutic)}

These are the locations that can be treated for healing purposes [11]. These marmani are comparatively safe, as the effect of wrong stimulation is usually less disastrous; these can be good starting points for inexperienced clinicians. These mainly include shakhagata marmani (of limbs) and prishthagata marmani (of back).

\section{III. a) External}

These are the marma points / sites located near the external surface or skin. These can be identified easily and manually stimulated. These include shakhagata marmani, marmani of supraclavicular region (like sthapani, apanga, simanta, krikatika), some marmani of back (like ansa, ansaphalaka, vrihati), etc.

\section{b) Internal}

These include the marma sites that are deeper inside the body, and are not easily located from outside; usually these are stimulated by using the corresponding skin zones or landmarks. These include all marmas of abdomen and chest, and some marmas of supra-clavicular region like adhipati, nila, manya, matrika, phana, shringataka, etc.

Instead of using the direct pressure technique, these marmani are stimulated through indirect applications, which include procedures like nasya, basti, pichu; use of some medications like ghee, oil, etc.; or by using asanas, pranayama, bandhas, etc.. 


\section{Classification of Methods of Marma Therapy}

The methods of Marma Therapy have been broadly classified into two categories, i.e. With Medicine (Pharmacological) and Without Medicine (Non-Pharmacological) [11-14], as can be seen in Figure 1.
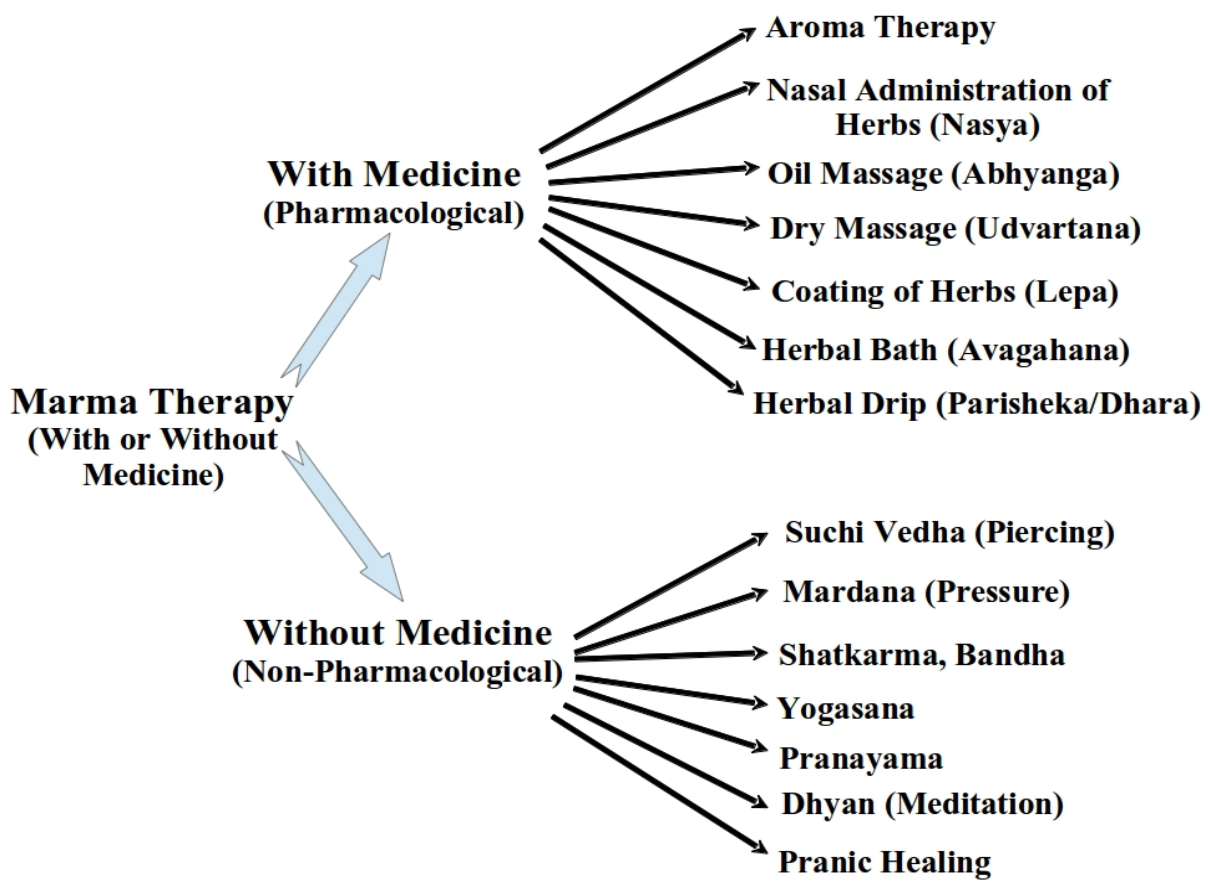

Figure 1. Classification of the methods of Marma Therapy - With and Without Medicine [1114]. 


\section{Therapeutic Applications of Marmas}

Several researchers have given the therapeutic applications of specific Marma points in different parts of the body; these have been listed in Table 1 to Table 5. For most of the Marma points, the web-links of videos depicting their method of stimulation, are also given in Table 1 to Table 5.

Table 1: Therapeutic Application of Marmas of Limbs (Upper Extremity (UE) and Lower Extremity (LE)) [7,11-14]

\begin{tabular}{|l|l|l|l|}
\hline $\begin{array}{l}\text { S. } \\
\text { N. }\end{array}$ & Marma & \multicolumn{1}{|c|}{ Therapeutic Application [7,11-14] } & \multicolumn{1}{c|}{$\begin{array}{c}\text { Method of } \\
\text { Stimulation }\end{array}$} \\
\hline $\begin{array}{l}\text { 1. } \\
\text { Talahridaya } \\
\text { (UE) }\end{array}$ & $\begin{array}{l}\text { Nervousness and restlessness, exhaustion, grief, sorrow, } \\
\text { indigestion, pain or stiffness in hand, nervous heart complaints, } \\
\text { circulatory disturbances, regulate blood pressure }\end{array}$ & $\begin{array}{l}\text { https://www.yout } \\
\text { ube.com/watch? } \\
\text { v=3DilE-gB3o4 }\end{array}$ \\
\hline
\end{tabular}

2. Talahridaya Nervousness and restlessness, exhaustion, grief, sorrow, sleeping https://www.yout (LE) disorders, digestive weakness, pain or tension in foot, nervous ube.com/watch? heart complaints, circulatory disorders, kidney disease $\quad v=3$ DilE-gB3o4

3. Kshipra Dissolving cramps, bronchial spasm in asthma, excitability with https://www.yout (UE) cramps, stimulation of lymphatic flow, colds, sore throat, ube.com/watch?

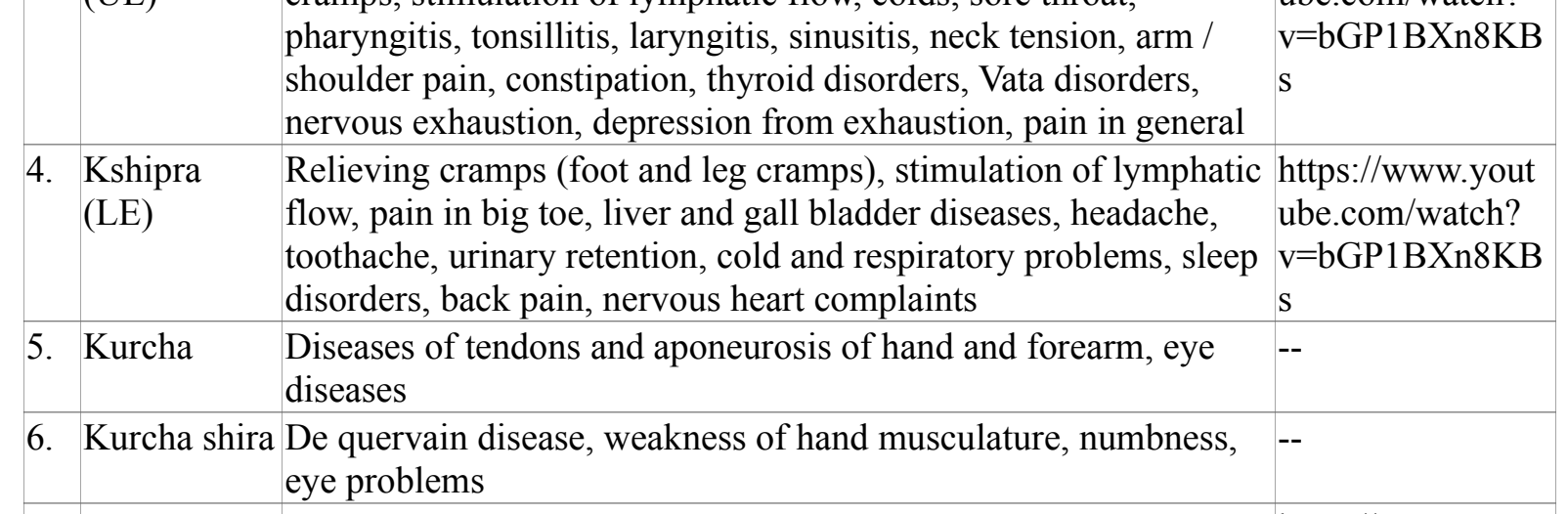

7. Manibandha Vata disorders, tension in the wrist, carpal tunnel syndrome, stress https://www.youtu induced bowel dysfunction, nervousness, weak concentration, be.com/watch? mental fatigue, insomnia, tinnitus, neck and back pain $\quad v=$ SgxpmAEA6w

8. Gulpha Anxiety, mental and physical insecurity, mental restlessness, https://www.yout sleeping disorders, lack of coordination in walking, disease of ube.com/watch? pelvic organs, sexual disorders, tinnitus, eye strain, restless leg $\quad \mathrm{v}=\mathrm{S} 27 \mathrm{kP} 5 \mathrm{vimT0}$ syndrome, lumbosacral spasm, prolapsed intervertebral disc (PIVD), Sciatica, lumbar sprain, reducopathies and neuropathies

9. Indravasti Indigestion, constipation, abdominal cramping, circulatory https://www.yout (UE) weakness, mental fatigue, sexual weakness, bladder weakness, ube.com/watch? arm pain $\quad \mathrm{v}=\mathrm{LX}$ LZ61H_rvs

10. Indravasti Back pain, sciatica, tired legs, calf pain and tightness after over- https://www.yout (LE) exertion, leg cramps, sexual disorders, gynaecological problems, ube.com/watch? prostate problems, haemorrhoids, mental dullness, tired eyes, $\quad \mathrm{v}=\mathrm{LXoZ61H}$ rvs lymphedema in legs, diabetic neuropathy, PIVD, peripheral vascular diseases, osteoarthritis of knee joint

11. Kurpara Tennis elbow, gastrointestinal disorders, circulation problems, https://www.yout depression, chest pain, trembling of the hands, neck/ shoulder/ ube.com/watch? back pain, aggression, cough, bronchial asthma, diabetes, hepatic $v=Y 9 t a V o Q T s T U$ (R) and splenic disease (L)

12. Janu Osteoarthritis of knee, knee-cap pain (chondropathia patellae), knee injury, artrosis / arthritis, anxiety, inner restlessness, sleep disorder, liver and bile problem, biliary pain $(\mathrm{R})$ and spleen and pancreatic disorder (L)

https://www.yout ube.com/watch? $\mathrm{v}=\mathrm{W} 1 \mathrm{M} 5 \mathrm{DL} 1 \mathrm{mo}$ $7 \mathrm{~g}$ 


\begin{tabular}{|c|c|c|c|}
\hline 13. & Ani (UE) & $\begin{array}{l}\text { Frozen shoulder, post-traumatic stiffness of elbow joint, restricted } \\
\text { movement of forearm, cardiovascular / respiratory / circulatory } \\
\text { problems }\end{array}$ & $\begin{array}{l}\text { https://www.yout } \\
\text { ube.com/watch? } \\
\text { v=lJDFtJkDRbA }\end{array}$ \\
\hline 14. & Ani (LE) & $\begin{array}{l}\text { Muscular pains, tendinitis, fatigue of thighs, osteoarthritis of knee } \\
\text { and hip joint, improving muscle strength - especially quadriceps }\end{array}$ & $\begin{array}{l}\text { https: } / / \text { www.yout } \\
\text { ube.com/watch? } \\
\text { v=lJDFtJkDRbA }\end{array}$ \\
\hline 15. & Urvi (UE) & $\begin{array}{l}\text { Pulmonary disorders, stiff shoulder, poor blood or lymphatic } \\
\text { circulation, improve lung function }\end{array}$ & $\begin{array}{l}\text { https://www.yout } \\
\text { ube.com/watch? } \\
\text { v=lJDFtJkDRbA }\end{array}$ \\
\hline 16. & Urvi (LE) & $\begin{array}{l}\text { Deep vein thrombosis (DVT), vericose veins, diabetic neuro- } \\
\text { angiopathy, lymphatic obstructions, peripheral vascular diseases, } \\
\text { burger's disease, increases the oxygenation of tissues of lower } \\
\text { limbs }\end{array}$ & $\begin{array}{l}\text { https: } / / \text { www.yout } \\
\text { ube.com/watch? } \\
\text { v=lJDFtJkDRbA }\end{array}$ \\
\hline & $\begin{array}{l}\text { Lohitaksha } \\
\text { (UE) }\end{array}$ & $\begin{array}{l}\text { Vascular obstructive diseases, neuro muscular disorders, } \\
\text { numbness, paresis and paralysis of upper limbs }\end{array}$ & -- \\
\hline & $\begin{array}{l}\text { Lohitaksha } \\
\text { (LE) }\end{array}$ & $\begin{array}{l}\text { Peripheral arterial disease, thromboangitis, neuro- angiopathies, } \\
\text { artherosclerosis, numbness, paresis and paralysis of lower limbs }\end{array}$ & -- \\
\hline 19.1 & Kakshadhara & $\begin{array}{l}\text { Muscular atrophy / dystrophy of upper limb, improves sensation } \\
\text { and movement of upper limb }\end{array}$ & -- \\
\hline 20. & Vitapa & $\begin{array}{l}\text { Sexual and reproductive problems like impotency, erectile } \\
\text { dysfunction, oligospermia, decrease lipido, gynaecological } \\
\text { disease like ovulatory problems, dysmenorrhoea, decreased } \\
\text { motility of fallopian tubes }\end{array}$ & $\begin{array}{l}\text { https://www.yout } \\
\text { ube.com/watch? } \\
\text { v=3um88wIONQ } \\
4\end{array}$ \\
\hline
\end{tabular}

Table 2: Therapeutic Application of Marmas of Back [7,11-14]

\begin{tabular}{|l|l|l|l|}
\hline $\begin{array}{l}\text { S. } \\
\text { N. }\end{array}$ & Marma & \multicolumn{1}{c|}{ Therapeutic Application [7,11-14] } & \multicolumn{1}{c|}{$\begin{array}{c}\text { Method of } \\
\text { Stimulation }\end{array}$} \\
\hline 1. Amsa & $\begin{array}{l}\text { Cervical spondylosis, frozen shoulder, neck spasm, reduces } \\
\text { stress, pain and tiredness in upper limbs, anxiety, headache } \\
\text { originating from the back of the neck }\end{array}$ & $\begin{array}{l}\text { https://www.youtu } \\
\text { be.com/watch? } \\
\text { v=43ddI7Bwjo8 }\end{array}$ \\
\hline 2. & Amsaphalaka & $\begin{array}{l}\text { Shoulder and arm pain, pain in upper back, paralysis and } \\
\text { numbness in the arm, improve shoulder movement, and reduce } \\
\text { stiffness and pain }\end{array}$ & $\begin{array}{l}\text { https://www.youtu } \\
\text { be.com/watch? } \\
\text { v=cErN52KBP3I }\end{array}$ \\
\hline 3. Vrihati & $\begin{array}{l}\text { Organic and psychological heart disease, heart failure, lung and } \\
\text { bronchial disease, cough, back pain and muscle spasm, sorrow, } \\
\text { lack of confidence, discouragement, inner tension }\end{array}$ & \\
\hline
\end{tabular}

4. Parshvasandhi Renal and adrenal gland diseases, reproductive and menstrual https://www.youtu disorders, increase immunity, reduces spasm of iliopsoas muscle, be.com/watch? back pain $\mathrm{v}=1 \mathrm{VoA}$ huQPrg

5. Nitamba good for skeletal system, lymphatic system, plasma and body fat, -kaphaj diseases

6. Kukundara Neuro-vascular diseases of lower back and lower limb, low https://www.youtu backache, sciatica, painful condition of lower limbs be.com/watch? $\mathrm{v}=\mathrm{y} 4$ RjcYFYYY

7. Katikataruna Reproductive and menstrual disorder, painful condition of pelvic https://www.youtu girdle, hip joint problems, avascular necrosis (AVN) of hip joint be.com/watch? $\mathrm{v}=\_\mathrm{wUpEruxHm}$ A 
Table 3: Therapeutic Application of Marmas of Abdomen [7,11-14].

\begin{tabular}{|l|l|l|}
\hline S. Marma & \multicolumn{1}{|c|}{ Therapeutic Application [7,11-14] } & \multicolumn{1}{c|}{$\begin{array}{c}\text { Method of } \\
\text { Stimulation }\end{array}$} \\
\hline 1. Guda & $\begin{array}{l}\text { Sexual disorders, menstrual disorders, ano-rectal disorders, prostate } \\
\text { disease, haemorrhoids, elimination disorders of the urinary tract and } \\
\text { colon, constipation, nervous weakness, fear of failure, existential fear }\end{array}$ & -- \\
\hline 2. Vasti & $\begin{array}{l}\text { Bladder diseases, irritable bladder, menstrual disorders, sexual } \\
\text { disorders, gynaecological problems, prostate disease, flatulence, colon } \\
\text { problems, back pain, hip pain, exhaustion and nervous disorders }\end{array}$ & $\begin{array}{l}\text { https://www.youtu } \\
\text { be.com/watch? } \\
\text { v=sQWgw76CDjI }\end{array}$ \\
\hline 3. Nabhi & $\begin{array}{l}\text { Indigestion, abdominal cramps, intestinal inflammation, crohn's } \\
\text { disease, ulcerative colitis, flatulence, restlessness, anxiety, loss of } \\
\text { balance in life }\end{array}$ & $\begin{array}{l}\mathrm{https} / / \mathrm{www} \text {.youtu } \\
\text { be.com/watch? } \\
\mathrm{v}=\mathrm{NfXF} \text { hg9vgw }\end{array}$ \\
\hline
\end{tabular}

Table 4: Therapeutic Application of Marmas of Thorax [7,11-14].

\begin{tabular}{|l|l|l|}
\hline S. Marma & \multicolumn{1}{|c|}{ Therapeutic Application [7,11-14] } & \multicolumn{1}{c|}{$\begin{array}{c}\text { Method of } \\
\text { Stimulation }\end{array}$} \\
\hline 1. Hridaya & $\begin{array}{l}\text { Nervous heart complaints, supportive treatment for organic and } \\
\text { vegetative heart disorders, circulatory disorders, stress related } \\
\text { high blood pressure, conducting abnormalities of heart, spinal } \\
\text { weakness, diseases of lungs and bronchial infections, sorrow, } \\
\text { strengthening of self confidence }\end{array}$ & $\begin{array}{l}\text { https://www.youtu } \\
\text { be.com/watch? } \\
\text { v=DjWXOvShM4 } \\
\mathrm{g}\end{array}$ \\
\hline 2. Stanamula & $\begin{array}{l}\text { Kaphaja disorders, obstructive respiratory problems like COPD, } \\
\text { asthma, keeps lungs healthy }\end{array}$ & $\begin{array}{l}\text { https://www.youtu } \\
\text { be.com/watch? } \\
\text { v=aCLBnQaH2Jg }\end{array}$ \\
\hline 3. Stanarohita & Kaphaja disorders, respiratory problems & $\begin{array}{l}\text { https://www.youtu } \\
\text { be.com/watch? } \\
\text { v=aCLBnQaH2Jg }\end{array}$ \\
\hline 4. Apalapa & Disorders of respiratory system & -- \\
\hline 5. Apasthambhat & Asthma, bronchitis, improves functioning of bronchial tree & -- \\
\hline
\end{tabular}


Table 5: Therapeutic Application of Marmas of Supra-clavicular region [7,11-14]

\begin{tabular}{|c|c|c|c|}
\hline S. & Marma & Therapeutic Application [7,11-14] & \begin{tabular}{|c|} 
Method of \\
Stimulation \\
\end{tabular} \\
\hline 1. & Nila & $\begin{array}{l}\text { Thyroid disease, speech problem, hoarseness, difficulty in } \\
\text { swallowing, laryngitis, tonsillitis, sorrow or anger that cannot be } \\
\text { expressed }\end{array}$ & $\begin{array}{l}\text { https://www.youtu } \\
\text { be.com/watch? } \\
\text { v=f65uqRXgkZg }\end{array}$ \\
\hline 2. & Manya & $\begin{array}{l}\text { Heavy tongue, excess flow of saliva or dry mouth, indigestion, } \\
\text { upper respiratory tract infections }\end{array}$ & $\begin{array}{l}\text { https://www.youtu } \\
\text { be.com/watch? } \\
\text { v=f65uqRXgkZg }\end{array}$ \\
\hline 3. & Matrika & $\begin{array}{l}\text { Autonomic dysfunction in the neck and circulatory disorders of } \\
\text { the head, speech disorders, throat problems, thyroid disorders }\end{array}$ & $\begin{array}{l}\text { https://www.youtu } \\
\text { be.com/watch? } \\
\text { v=f65uqRXgkZg }\end{array}$ \\
\hline 4. & Krikatika & $\begin{array}{l}\text { Neck tension, neck pain, stiff neck, blockage of the } 1 \text { st and } 2 \text { nd } \\
\text { cervical vertebrae, pain in back of the head, tremors in head and } \\
\text { neck (as in parkinsonism), anxiety, shoulder pain, migraine }\end{array}$ & $\begin{array}{l}\text { https://www.youtu } \\
\text { be.com/watch? } \\
\text { v=hynKgLR0sWw }\end{array}$ \\
\hline 5. & Vidhura & Deafness, tinnitus, neck pain, ear pain, anxiety & $\begin{array}{l}\text { https://www.youtu } \\
\text { be.com/watch? } \\
\text { v=b_BtP71Src }\end{array}$ \\
\hline 6. & Phana & $\begin{array}{l}\text { Anosmia, allergic rhinitis, sneezing, wheezing, bronchial asthma, } \\
\text { recurrent cold and flu }\end{array}$ & $\begin{array}{l}\text { https://www.youtu } \\
\text { be.com/watch? } \\
\text { v=2G40spsVo2M }\end{array}$ \\
\hline 7. & Apanga & $\begin{array}{l}\text { Eye strain, defective vision, headache resulting from strained } \\
\text { eyes, blocked nose, glaucoma }\end{array}$ & $\begin{array}{l}\text { https://www.youtu } \\
\text { be.com/watch? } \\
\text { v=v93 YEHuc5HA }\end{array}$ \\
\hline 8. & Avarta & Same as of Apanga, frontal sinusitis, ptosis & $\begin{array}{l}\text { https://www.youtu } \\
\text { be.com/watch? } \\
\text { v=5aQ5LtJOYzE }\end{array}$ \\
\hline 9. & Utkshepa & $\begin{array}{l}\text { Headache (especially at temples), dizziness, nausea, mental over- } \\
\text { exertion, teeth grinding, sleep disorder due to anger or strain, } \\
\text { nasal congestion, rhinitis, strained eyes, gall bladder ailments }\end{array}$ & $\begin{array}{l}\text { https://www.youtu } \\
\text { be.com/watch? } \\
\text { v=5aQ5LtJOYzE }\end{array}$ \\
\hline 10. & Shankha & Same as of Utkshepa & $\begin{array}{l}\text { https://www.youtu } \\
\text { be.com/watch? } \\
\text { v=5aQ5LtJOYzE }\end{array}$ \\
\hline
\end{tabular}

11. Sthapani Nervousness, insomnia, hormonal disorders, headache (especially https://www.youtu at forehead region), overstrained eyes, visual impairment, worry, be.com/watch? $==-$ grief, anxiety, narrow mindedness, nervous heart complaints, for dTBuifPF-w strengthening of self confidence, improving memory and perception power

12. Shringataka Nervous weakness, taste disorders, disorders of salivary glands, disturbance of vision, hearing and smell, sinusitis, recurrent cold, improve peace of mind

13. Simanta Nervousness, insomnia, anxiety, fatigue, headache, neck tension, https://www.youtu circulatory insufficiency, opens up various channels (srotansi), be.com/watch? induces calmness

14. Adhipati Nervousness, insomnia, anxiety, fatigue, confused thinking, headache, increasing vital energy and perceptive powers $\mathrm{v}=\mathrm{cH} 69 \mathrm{FlVAxIg}$ https://www.youtu be.com/watch? $\mathrm{v}=2 \mathrm{op} 0 \mathrm{gdlOutA}$ 


\subsection{Research Studies that Demonstrate the Benefits of Marma Therapy}

Several research studies have demonstrated the encouraging outcomes of Marma Therapy in the treatment of various diseases; some such studies are described as follows.

(1) A study on anatomical concept of kurpara marma and its therapeutic application in grivavata (cervical spondylosis) (Pathak, 2015) [21]

This study was done on 300 cases of Griva Vata (Cervical Spondylosis), aged between 20-65 years, from Kayachikitsa OPD and IPD of Sir Sunderlal Hospital, Institute of Medical Sciences, Banaras Hindu University, Varanasi, Uttar Pradesh, India. All 300 cases were divided randomly into 3 separate groups consisting of 100 cases in each group. Group A was treated with Dashamula Ghana Vati (2 tablets, three times in a day, after meal, with lukewarm water); Group B was treated with Dashamula Ghana Vati + palcebo points; and, Group C was treated with Dashamula Ghana Vati + Kurpara Marma Chikitsa (Marma Therapy) (3 times in a day); treatment was given to all the three groups for 45 days, with a follow-up time period of 15 days. On completion of the study, maximum beneficial effect was found in Group C, on all the signs and symptoms of Griva Vata; this showed the efficacy of Marma Therapy in the management of Cervical Spondylosis.

(2) A critical study of gulpha marma in basket ball players with special reference to the role of mash tail along with snehan and swedan as preventive measure (Bedekar, 2007) [23]

This study was done on basketball players of age group 13-20 years. The experimental group consisted of 30 players, who were selected based on having Ankle Sprain, and were treated with Mash tail snehan and warm water swedan on Gulpha Marma, for 30 days; a control group of players was also selected, who applied crape bandage while playing the game. The assessment was done at day 0 , day 15 and day 30. In the experimental group, on day 0 the pain was moderate, which reduced to $50 \%$ on day 15 and completely disappeared on day 30; while in the control group, the pain persisted up to day 30. It showed the effectiveness of the administered therapy on Gulpha Marma.

(3) A comprehensive study on marma and acupuncture points and evaluation of their therapeutic importance (Vivek, 2011) [25]

This study was done on 40 patients of age group 40-75 years, having signs and symptoms of Janu Sandhigata Vata. These 40 patients were divided into 2 groups, Group A and Group B, each consisting of 20 patients. Patients of Group A were treated daily by Suchivyadha on Janu Marma for 12 sessions and for about 30 minute duration; and, patients of Group B were treated daily by Acupuncture on Acupuncture points for 12 sessions and for about 30 minute duration. On completion of study, significant response was observed on all the subjective and objective parameters, in both the groups. Thus, this study revealed the efficacy of treatment administered over Janu Marma for the management of Janu Sandhigata Vata.

(4) A study on rujakara marma and management of viddha laxanas - a clinical study (Rajeshwari, 2010) [24]

This study was done on 20 subjects from Department of PG studies in Shalya Tantra, Sri Jayachamarajendra Institute of Indian Medicine (SJIIM) Hospital, Bangalore and Padmashree Institute of Physiotherapy, Nagarabavi, Bangalore (Karnataka, India), to assess the efficacy of Ashwagandha taila in the management of Rujakara marma viddha laxanas (symptoms upon injury). Subjects with Rujakara marmabhighata (injury to the marma) were selected having features such as pain, swelling, and restricted movement. Cotton soaked in taila was placed over the marma viddha pradesha, and bandaging was done daily for 15 days. Periodical observations were carried out on $5^{\text {th }}$ day, $10^{\text {th }}$ day, and $15^{\text {th }}$ day, with a follow-up time period of 15 days from the completion of treatment. Pressure Algometer was used to detect the pain threshold in Manibandha, Gulpha and Kurchasira marma pradesha (region), comparing it with the readings of sites away from the marma pradesha. Significant change (reduction) was observed in pain threshold before and after the treatment, showing the efficacy of oil application over Rujakara marmas. 
(5) Evaluation of efficacy of marma therapy with janu basti in the management of janu sandhigata vata (osteoarthritis of knee) (Mishra and Shrivastava, 2020) [30]

This study was done to evaluate the efficacy of Marma Therapy with Janu Basti (with Ksheerbala Taila) in the management of Janu Sandhigata Vata (Osteoarthritis of knee). The therapeutic procedure involved administration of Marma Therapy on four Marma points of the legs, i.e. Kshipra, Gulpha, Indravasti and Janu, three times during the day, and, Janu Basti with Ksheerbala Taila, followed by Nadi Sweda of Dashamoola Kwath. The total time duration of therapy was 65 to 75 minutes per day, and this intervention was given for 9 days. After that there was a followup time period of one month, during which the patient had to daily do the massage of the affected knee with Ksheerbala Taila, followed by plain water hot fomentation, as well as three sessions of Marma Therapy, wherein each session included applying pressure on each of the four Marma points, 16 to 20 times. Twenty patients completed the study, which involved the treatment of 30 knees.

With regards to the management of the symptoms of Janu Sandhigata Vata, Significant improvement was observed in the subjective parameters (Sandhi Shoola, Sandhi Shotha, Sandhi Stabdhata, and Sandhi Atopa) and objective parameters (WOMAC Index, ROM, Walking Time) analyzed during the study. Both during the initial therapeutic intervention of nine days, as well as the followup time of one month, there was continuous decrease in the mean values of all the subjective and objective parameters with the duration of intervention, indicating the efficacy of the therapeutic procedure. This also indicated that after the short-term initial therapeutic intervention, the patients attained the capability of long term self-management of the disease at home through regular practice of Marma Therapy and massage. Verbal feedback taken from patients about six months after the completion of the study period indicated that 4 patients still had almost complete relief (who had chronicity of less than 3 years) and were pursuing Marma Therapy regularly, while 10 others were able to self manage the disease through regular Marma Therapy and massage (who had chronicity of 3 to 10 years). These observations indicated the specific efficacy of Marma Therapy in the long-term self-management of Janu Sandhigata Vata.

(6) Optimization of individual performance in football by augmenting classical Indian marma therapy, kinesiology-taping and related physical exercises through supportive bio-mechanical parameter (Dharmesh, 2017) [22]

This study was done on 40 subjects, which were district level football players, aged between 18-25 years. They were divided into four groups (10 subjects in each group) namely Marma group, Kinesio taping group, Physical exercise group, and Control group; the aim of the study was to analyze the improvement in various parameters associated with the leg movement, kick, etc., by the use of these techniques. The training program was conducted for a period of 24 weeks. The Ayurvedic Marma stimulation was performed, in which muscular stimulations were given to reduce the related muscular knots and stiffness, during the training period. Marma therapy were given for 25 minutes per session, on alternate days. The pre and post tests were recorded for all the subjects, before and after the training, respectively. Significant improvement was observed from Marma Therapy in various parameters, and it was concluded that Marma Therapy should be useful in enhancing the performance of the football players.

(7) Physical and psychological effects of head treatment in the supine position using specialized ayurveda-based techniques (Murota et al., 2016) [19]

This study was performed on 24 female students, to assess the physical and psychological effects of head massage, performed in the supine position, using Ayurveda-based techniques (head treatment). This was a crossover study design, wherein the same participants were enrolled in both the head treatment intervention group, and control group; there was an interval of one week or more between measurements. The physiological indices measured included blood pressure and heart rate fluctuations. The psychological markers measured included liveliness, depression and boredom, using the Visual Analogue Scale method. State anxiety was measured using the State-Trait Anxiety Inventory method. The head treatment was performed by using the 7-minute head treatment program (head massage was done on marma points) in the supine position. At the end of the study, the results suggested that performing a head treatment not only decreased depression, boredom, and anxiety, but 
also markedly increased liveliness. The results of the study demonstrated the administered head treatment as a massage technique that offers relaxing and refreshing effects; thus, it also revealed the efficacy of Marma Therapy.

(8) Integrative technology of massage manipulations in physical rehabilitation of students with backbone pathology (Kotelevskiy, 2016) [18]

This study was done on 195 students, in 19-20 years age group, to analyze the effectiveness of an integrative technology including massage manipulations, in physical rehabilitation of students of higher education institutions, suffering from backbone pathology. All students had periodical initial neurological symptoms of functional pathology and first stage osteochondrosis in different parts of backbone. All 195 students were divided into six groups; one of these groups of 34 students passed rehabilitation with elements of Ayurvedic marma massage. A course of 10 sessions of therapeutic massage (marma massage) was conducted. On completion of the study, change in the pain index (reduction) was found to be $75.59 \pm 2.26 \%$ in case of application of Ayurvedic massage elements. Thus, integrative massage technology was found more effective on general psycho-emotional state of young people, and facilitated improvement of backbone functional state.

Along the same lines as Marma Therapy, in Siddha system 'Varman Therapy' is found, which has been practiced in South India (especially in Tamil Nadu region) for the treatment of various ailments like neurological weakness, neuromuscular problems, migraine headaches, convulsions, arthritis, spinal problems, muscle wasting, and to relieve intense pain, etc. [52]. Janani and Manickavasagam (2017) [52] administered Varman Therapy to 30 patients for the management of Osteoarthritis of knee and found encouraging results in this regard.

Thus, Marma Therapy has been shown to be an effective approach in the management of various ailments.

\section{Mechanism of Marma Therapy}

Several mechanisms for the mode of action of Marma Therapy have been suggested in the literature; some of these may be understood through various ancient and modern concepts as follows [30].

According to the scriptures, 'Havya Vaha' and 'Kavya Vaha' Tadit Shakti (bio-electric power), resides in the Marma locations [55]. The positive electricity named 'Havya Vaha' resides in the Marmas of the head and the torso, while the negative electricity named 'Kavya Vaha' resides in the Marmas of the hands and legs [55]. Imbalance of the Havya Vaha and Kavya Vaha Tadit Shakti residing in the Marma points results in the occurrence of disease and weakness [55]. In order to provide relief from this suffering by regaining this balance, the ancient sages invented Yogasanas (Yogic postures) [55]. The stretching, vibration, rhythmic movement and pressure caused by Yogasanas have a direct influence on the Marma points, and play an important role in their refinement, stability and nourishment [7,9,11,55]; subsequently, the functioning of the respective organs with which the specific Marmas are associated, also gets affected leading to therapeutic benefits [7]. For example, Kshipra, Gulpha, Indravasti and Janu Marmas are stimulated during Vajrasana and Supta Vajrasana, which are useful for knee pain/ strengthening of knee in a healthy person [9]; this indicates the effectiveness of the stimulation of these Marma points in knee disorders.

Marmas are connected to the Nadis (subtle nervous system) and Chakras (subtle energy centers) of the subtle body $[11,28]$. The Chakras can be considered to correspond to seven main Marmas or Pranic centers, which provide energy to all other Marmas [11,14]. Through stimulation of Marma points, the flow of Prana through the Chakras can be stimulated, thus activating them; the activation of the Chakras results in the awakening of subtle dormant areas in the brain, that leads to the experiencing of higher realms of consciousness, which are normally inaccessible [56]; this, in turn, can lead to better control over the mind-body network including the autonomic nervous system and various organs, resulting in an overall healing effect [11].

Marmas are related to the three Doshas (Vata, Pitta and Kapha). According to Ayurveda, a healthy human body is supposed to have a relatively stable equilibrium of the three Doshas (Vata, 
Pitta and Kapha) [1]. Imbalance in this equilibrium leads to disease, and the aim of the therapy is to restore this balance [1]. Therefore, the Ayurvedic therapies seek to maintain or restore this balance. Schrott et al. (2016) [13] state that the Marma Therapy is especially effective in this regard, as these Doshas reside in the Marmas, and determine their proper functioning or blocked state, as well as the occurrence of defects or energetic weakness at these locations. Acharya Charaka has assigned great importance to the Trimarmas, i.e. Basti, Hridaya and Shirah [45]; these three main Marmas seem to have a direct relationship with the three Doshas, that are known to primarily reside in the same regions, i.e. Vata in the lower abdomen (site of Basti Marma), Pitta in the heart region (site of Hridaya Marma) and Kapha in the head area (site of Shirah Marma) [13]. According to Acharya Sushruta [Sushruta Sharira 6/35] [1], Marmas are the locations having the presence of the three Doshas (Vata, Pitta, Kapha), as well as their subtle forms, i.e. Prana, Tejas, Ojas, and also the three Gunas, i.e. Sattva, Rajas and Tamas [11]. Thus, the stimulation of Marmas may be correlated with the balance of the three Doshas and their subtle forms (Prana, Tejas, Ojas), as well as the three Gunas, which includes Sattva (mind) [11]. Ojas signifies the immunity power; by properly balancing it through the appropriate stimulation of Marmas, the immune system may be strengthened, as well as it can cause rejuvenating effect [11]. Through the connection with the Sattva Guna (mind), the proper stimulation of Marmas can provide relief in stress [11].

As Marmas are the seats of Prana, the vital life force that governs the physical and subtle processes of the body, the stimulation of Marmas can alter the state of Prana at these locations, causing a corresponding effect on the physical and subtle processes, and the flow of energy $[11,55]$. Therefore, by the proper stimulation of Marmas, the Prana can be modulated in such a way that it can be used to remove blockages, and decrease or enhance the physical and subtle energy currents within the body, resulting in the corresponding healing effect $[11,28,55]$.

Since Prana is connected to Vata Dosha, whose vitiation leads to the maximum types of diseases, hence Marma Therapy can be especially useful in treating the Vata disorders, which correspond to chronic degenerative diseases [11,28]. Out of the five forms of Vata Dosha, Vyana Vayu, that is associated with the skin, as well as the movement and circulation of the Prana, can be most closely linked to the Marmas [11,28,38]. Thus, stimulation of the Marmas can balance the Vyana Vayu and Vata Dosha [28], resulting in the corresponding healing effect.

Figure 2 gives an overview of the Mechanism of Marma Therapy with reference to managing the flow of Prana in the body, and the corresponding beneficial outcomes [11,55].

\section{Conclusion}

The present article explored the foundational elements of the Science of Marma with regards to its use as a therapeutic procedure (Marma Therapy), as well as the recent applications of this healing method.

It is observed that various ancient Indian traditions, and several researches in recent times have used the technique of stimulating the Marmas for therapeutic benefits. Different methods have been used for stimulating and affecting the Marmas. The Marmas have been classified according to their therapeutic use. The therapeutic applications of individual Marmas have been compiled, as well as a brief description of several research studies has been included in the article that demonstrate the benefits of Marma Therapy in various ailments.

Several mechanisms for the mode of action of Marma Therapy, as suggested in the literature, have been discussed. The special capability of this therapeutic procedure in treating Vata disorders, that correspond to chronic degenerative diseases, has also been highlighted.

Thus, it can be concluded that Marma Science, which is an extremely ancient field of knowledge, holds significant promise in being used as an effective therapeutic procedure. 


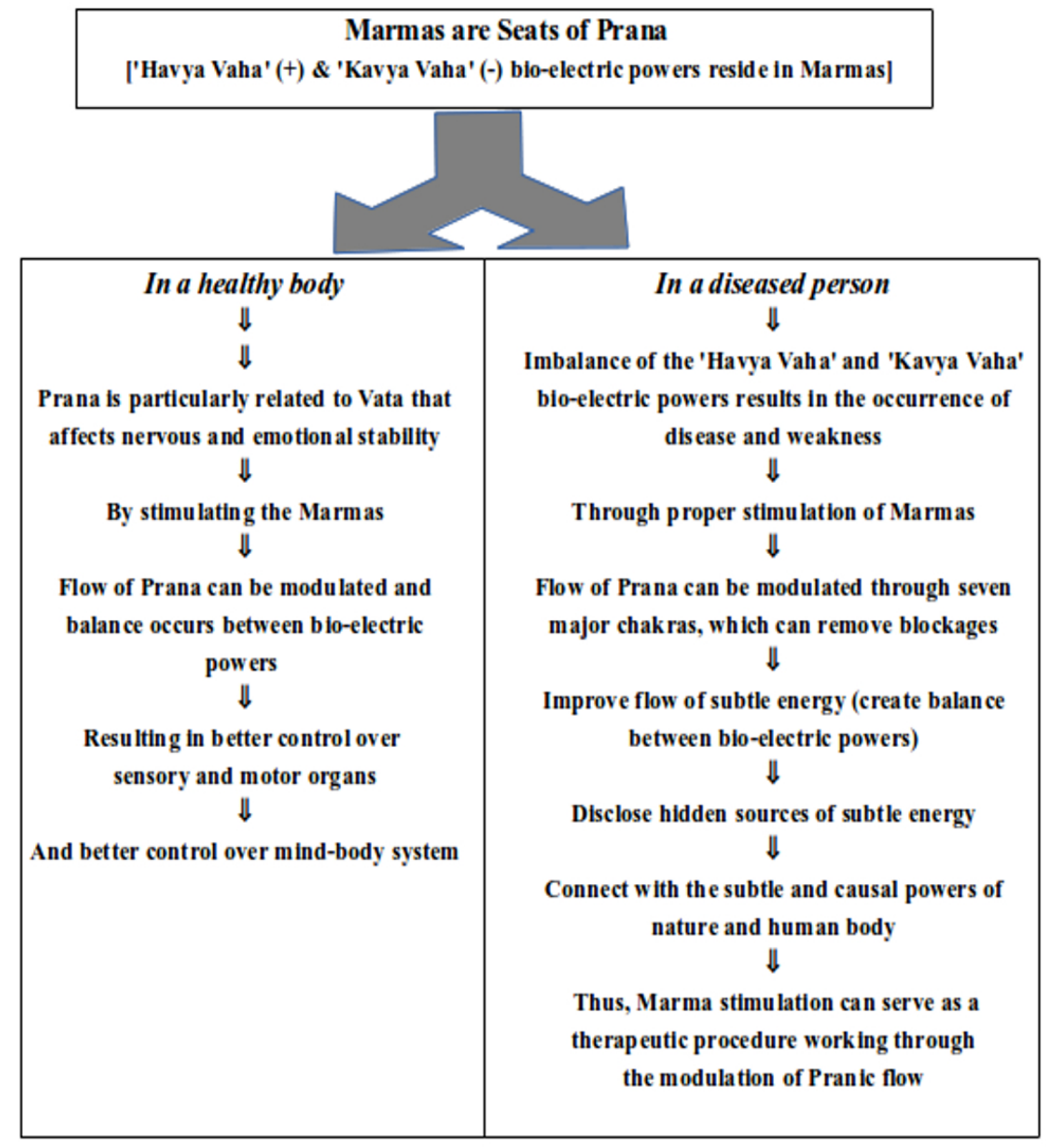

Figure 2: Mechanism of Marma Therapy with reference to managing the flow of Prana in the body, and the corresponding beneficial outcomes $[11,55]$.

\section{Acknowledgements}

Authors would like to acknowledge the subtle guidance of their spiritual guide, Revered Pandit Shriram Sharma Acharya (http://www.awgp.org/about_us/patron_founder). The authors thank the faculty and staff of the Department of Ayurveda and Holistic Health at Dev Sanskriti Vishwavidyalaya, Haridwar for their support in conducting this study.

Compliance with ethical standards: The authors have maintained necessary ethical standards while conducting the study.

Conflict of interest: The authors declare that they have no conflict of interest. 


\section{References}

1. Murthy KRS. Susruta samhita. volume I, II, III. Varanasi, Uttar Pradesh, India: Chaukhambha Orientalia; 2008.

2. Gupta KA. Ashtanga hrdyam of vagbhata - vidyotini hindi commentary. Varanasi, Uttar Pradesh, India: Chaukhamba Sanskrit Sansthan; 2005.

3. Brahmavarchas. Pranashakti : ek divya vibhuti (Hindi). Pandit Shriram Sharma Acharya samagra vangamaya. volume 17. 2nd ed. Mathura, Uttar Pradesh, India: Akhand Jyoti Sansthan; 1998.

4. Sharma, S. Kaya me samaya, pranagni ka jakhira (Hindi). Gayatri Tapobhumi, Matura, Uttar Pradesh, India: Yug Nirman Yojana Vistar Trust; 2010.

(http://literature.awgp.org/book/kaya_men_samaya_pranagni_ka_jakheera/v1.1)

5. Sharma, S. Kaya urja evam usaki chamatkari samarthya (Hindi). Gayatri Tapobhumi, Matura, Uttar Pradesh, India: Yug Nirman Yojana Vistar Trust; 2010.

(http://literature.awgp.org/book/astonishing_power_of_physical_subtle_energy_of_human/v2.2)

6. Sharma, S. The astonishing power of the bio-physical and subtle energies of the human body. Haridwar, India: Shantikunj; 1996.

(http://literature.awgp.org/book/astonishing_power_of_physical_subtle_energy_of_human/v1.1)

7. Joshi SK. Marma science and principles of marma therapy. 1st ed. Haridwar, Uttarakhand, India: Vani Publications; 2010.

8. Joshi SK. Marma vigyan evam chikitsa - vaidik chikitsa vigyan (Hindi). Haridwar, Uttarakhand, India: Mrityunjay Mission; 2011.

9. Joshi SK. Marma chikitsa vigyan (Hindi). Haridwar, Uttarakhand, India: Mrityunjay Mission; 2012.

10. Joshi SK. Marma vigyan evam aushadhopachar dwara chikitsa (Hindi). Haridwar, Uttarakhand, India: Mrityunjay Mission; 2013.

11. Frawley D, Ranade S, Lele A. Ayurveda and marma therapy. Delhi, India: Chaukhamba Sanskrit Pratishthan; 2015.

12. Lad V, Durve A. Marma points of ayurveda. Albuquerque, New Mexico, USA: The Ayurvedic Press; 2015.

13. Schrott E, Raju JR, Schrott S. Marma therapy. (Translated by) Lorys M. London, UK: Singing Dragon; 2016.

14. Phull G, Phull R. Clinical approach to marma chikitsa. New Delhi, India: IP Innovative Publication Pvt. Ltd.; 2019.

15. Phull G, Phull R. Marma vigyana ka chikitsiya upayoga (Hindi). New Delhi, India: IP Innovative Publication Pvt. Ltd.; 2019.

16. Denaud P. Kalaripayat - the martial arts tradition of India. (Translated by) Cain J. Vermont, USA: Destiny Books; 2009.

17. Fox M, Dickens A, Greaves C, Dixon M, James M. Marma therapy for stroke rehabilitation - a pilot study. Journal of Rehabilitation Medicine. 2006;38(4):268-271. DOI: 10.1080/16501970600630820. (https://www.medicaljournals.se/jrm/content_files/download.php?doi=10.1080/16501970600630820)

18. Kotelevskiy VI. Integrative technology of massage manipulations in physical rehabilitation of students with backbone pathology. Pedagogics, Psychology, Medical-Biological Problems of Physical Training and Sports. 2016;20(3):31-40. http://dx.doi.org/10.15561/18189172.2016.0305.

(https://www.sportpedagogy.org.ua/html/journal/2016-03/html-en/16kviwbp.html)

19. Murota M, Iwawaki Y, Uebaba K, Yamamoto Y, Takishita Y, Harada K, Shibata A, Narumoto J, Fukui $\mathrm{K}$. Physical and psychological effects of head treatment in the supine position using specialized ayurveda-based techniques. The Journal of Alternative and Complementary Medicine. 2016;22(7):526-532. DOI: 10.1089/acm.2015.0388.

(https://www.ncbi.nlm.nih.gov/pmc/articles/PMC4939366/)

20. Sieler R. Kalari and vaittiyacalai: medicine and martial arts intertwined. Asian Medicine. 2012; 7(1): 164-195. https://doi.org/10.1163/15734218-12341247.

(https://brill.com/view/journals/asme/7/1/article-p164_7.xml?language=en)

21. Pathak AK. A study on anatomical concept of kurpara marma and its therapeutic application in grivavata (cervical spondylosis). Thesis for the degree of Doctor of Philosophy (Ph.D.) in Rachana Sharir. Varanasi, Uttar Pradesh, India: Banaras Hindu University; 2015.

(https://shodhganga.inflibnet.ac.in/handle/10603/267960) 
22. Dharmesh K. Optimization of individual performance in football by augmenting classical Indian marma therapy, kinesiology-taping and related physical excercises through supportive bio-mechanical parameter. Thesis for the degree of Doctor of Philosophy (Ph.D.) in Physical Education. Tiruchirappalli, Tamil Nadu, India: Bharathidasan University; 2017. (https://shodhganga.inflibnet.ac.in/handle/10603/220290)

23. Bedekar SS. A critical study of gulpha marma in basket ball players with special reference to the role of mash tail along with snehan and swedan as preventive measure. Thesis for the degree of Doctor of Philosophy (Ph.D.) in Ayurved. Pune, Maharashtra, India: Tilak Maharashtra Vidyapeeth; 2007. (https://shodhganga.inflibnet.ac.in/handle/10603/34851)

24. Rajeshwari PN. A study on rujakara marma and management of viddha laxanas - a clinical study. Dissertation for the degree of Ayurveda Dhanwanthari (M.S.-Shalya Tantra). Bengaluru, Karnataka, India: Rajiv Gandhi University of Health Sciences; 2010.

(http://52.172.27.147:8080/jspui/handle/123456789/6831)

25. Vivek J. A comprehensive study on marma \& acupuncture points and evaluation of their therapeutic importance. Dissertation for the degree of Master of Surgery (Ayurveda Dhanvantari) in Shalya Tantra. Bengaluru, Karnataka, India: Rajiv Gandhi University of Health Sciences; 2011. (http://52.172.27.147:8080/jspui/handle/123456789/4737)

26. Lele A, Ranade S, Frawley D. Secrets of marma - the lost secrets of ayurveda. Delhi, India: Chaukhamba Sanskrit Pratishthan; 2005.

27. Srivastava VK, Srivastava A. Hand book on marma and panchakarma therapy. Varanasi, Uttar Pradesh, India: Chaukhambha Orientalia; 2019.

28. National Health Portal. Marma therapy. National Health Portal, Centre for Health Informatics, National Institute of Health and Family Welfare (NIHFW), Ministry of Health and Family Welfare, Government of India. [cited 2020 February 29]. Available from: https://www.nhp.gov.in/marma-therapy mtl

29. Babu SR, Iyer VB. Varmam - an insight into the ancient system of healing. Hosur, Tamil Nadu, India: Varma Kalpa Rejuvenation Center; 2017.

30. Mishra A, Shrivastava V. Evaluation of efficacy of marma therapy with janu basti in the management of janu sandhigata vata (osteoarthritis of knee). Dev Sanskriti Interdisciplinary International Journal. 2020; 15: 29-45. https://doi.org/10.36018/dsiij.v15i.139. (http://dsiij.dsvv.ac.in/index.php/dsiij/article/view/139/134)

31. Banjare H. Marma - eka adhyayana, acupressure chikitsa paddhati ke vishesha shandarbha me. Dissertation for the degree of Ayurveda Vachaspati (M.D. - Ayurveda) in Rachana Sharira. Raipur, Chhattisgarh, India: Pt. Ravishankar Shukla University; 2009.

(https://shodhganga.inflibnet.ac.in/handle/10603/41426)

32. Ismail SMB. Marmas in ayurveda and their explanation according to modern anatomy. Thesis for the degree of Doctor of Philosophy (Ph.D.) in Ayurveda. Pune, Maharashtra, India: Savitribai Phule Pune University; 1984.

(https://shodhganga.inflibnet.ac.in/handle/10603/145863)

33. Kumar CS. A comprehensive study of marmas with special reference to Ayurvedic and Tamil marma sastras in relation to its applied anatomy. Thesis for the degree of Doctor of Philosophy (Ph.D.) in Ayurveda. Kalady, Kerala, India: Sree Sankaracharya University of Sanskrit; 1999. (https://shodhganga.inflibnet.ac.in/handle/10603/136019)

34. Muley SK. Ayurvediya sanhitokta marma vichara, vaikalyakara marmanche mahatva evam janumarmachya vaikalyakaratvachi uparugna paddhatine punarpadatalani eka abhyasa (Marathi). Thesis for the degree of Doctor of Philosophy (Ph.D. - Ayurveda) in Sharira Rachana. Nanded, Maharashtra, India: Swami Ramanand Teerth Marathwada University; 2007.

(https://shodhganga.inflibnet.ac.in/handle/10603/240135)

35. Parameswaran S. A comprehensive study on sandhi marma shareera w.s.r. to manibandha marma and its injuries (trauma). Dissertation for the degree of Doctor of Medicine (M.D. - Ayurveda) in Shareera Rachana. Bengaluru, Karnataka, India: Rajiv Gandhi University of Health Sciences; 2012. (http://52.172.27.147:8080/jspui/handle/123456789/7127)

36. Vijayanath V. A comprehensive study of marmas in the hasta (hand) w.s.r. to the surface and regional anatomy (cadaver dissection). Dissertation for the degree of Doctor of Medicine (M.D. - Ayurveda) in Shareera Rachana. Bengaluru, Karnataka, India: Rajiv Gandhi University of Health Sciences; 2011. (http://52.172.27.147:8080/jspui/handle/123456789/4578) 
37. Vipin PC. A comprehensive study on gulpha sandhi shareera w.s.r. to sports injuries. Dissertation for the degree of Doctor of Medicine (Ayurveda) in Shareera Rachana. Bengaluru, Karnataka, India: Rajiv Gandhi University of Health Sciences; 2011.

(http://52.172.27.147:8080/jspui/handle/123456789/4579)

38. Thatte DG. Acupuncture, marma and other asian therapeutic techniques. Varanasi, Uttar Pradesh, India: Chaukhambha Orientalia; 2015.

39. Fedorova M. Die Marmantheorie in der klassischen indischen Medizin (German) (English translation of the title - the marma theory in classical Indian medicine). Thesis for the degree of Doctor of Philosophy (Ph.D.). Munich, Bavaria, Germany: Ludwig-Maximilians-Universität München; 1990. (https://archive.org/details/DieMarmantheorieInDerKlassischenIndischenMedizinFedorova1990/page/n12/mode/2up)

40. Pathak AK. Anatomy of marma. (Editor) Awasthi HH. Varanasi, Uttar Pradesh, India: Chaukhambha Orientalia; 2014.

41. Mishra JN. Marma and its management. Varanasi, Uttar Pradesh, India: Chaukhambha Orientalia; 2016.

42. Govindan SV. Massage therapy for diseases of vital areas (marma treatment). New Delhi, India: Abhinav Publications; 2005.

43. Gupta KA. Astanga samgraha (with Hindi commentary) (Hindi). part 1, 2. Varanasi, Uttar Pradesh, India: Chowkhamba Krishnadas Academy; 2016.

44. Murthy KRS. Astanga samgraha of Vagbhata (text, English translation, notes, indices, etc.). volume II sarira, nidana, cikitsita and kalpa sthana. Varanasi, Uttar Pradesh, India: Chaukhambha Orientalia; 2018.

45. Sharma PV. Charaka-samhita (text with English translation). volume I, II. Varanasi, Uttar Pradesh, India: Chaukhambha Orientalia; 2008.

46. Mishra A, Shrivastava V. Exploring the science of marma - an ancient healing technique - part 1: its mention in ancient Indian scriptures. submitted to the Dev Sanskriti Interdisciplinary International Journal (http://dsiij.dsvv.ac.in/). February 2020.

47. Mishra A, Shrivastava V. Exploring the science of marma - an ancient healing technique - part 2: definition and properties of marma. submitted to the Dev Sanskriti Interdisciplinary International Journal (http://dsiij.dsvv.ac.in/). February 2020.

48. Mishra A, Shrivastava V. Exploring the science of marma - an ancient healing technique - part 3: marma in yoga and other ancient Indian traditions. submitted to the Dev Sanskriti Interdisciplinary International Journal (http://dsiij.dsvv.ac.in/). March 2020.

49. Sharma S, Sharma BD. 108 Upanishad - brahmavidya khand - saral Hindi bhavarth sahit (Hindi). Gayatri Tapobhumi, Mathura, Uttar Pradesh, India: Yug Nirman Yojna Vistar Trust; 2015.

50. Digambarji S, Jha P, Sahay GS. Vasistha samhita (yoga kanda). Lonavla, Pune, Maharashtra, India: Kaivalyadhama; 2017.

51. Zarrilli PB. When the body becomes all eyes - paradigms, discourses and practices of power in kalarippayattu, a south Indian martial art. New Delhi, India: Oxford University Press; 2001.

52. Janani L, Manickavasagam R. Effectiveness of varmam therapy for the management of osteoarthritis. International Journal of Pharmaceutical Sciences and Research. 2017; 8(12): 5286-5290. DOI: 10.13040/IJPSR.0975-8232.8(12).5286-90. (http://ijpsr.com/bft-article/effectiveness-of-varmamtherapy-for-the-management-of-osteoarthritis/?view=fulltext)

53. Mozhi AP, Pattarayan R, Deivanayagi S. The effect of brahmi nei with massage and varmam on spasticity of cerebral palsy children. Global Journal for Research Analysis. 2016; 5(11): 181-183. (https://www.worldwidejournals.com/global-journal-for-research-analysis-

GJRA/fileview/November_2016_1479128687_17.pdf)

54. Sridhar S, Senthilvel G. Efficacy of classical siddha external therapy "suttigai" (thermal cauterization) on azal keel vaatham. IOSR Journal of Dental and Medical Sciences. 2018; 17(9): 1-11. DOI: 10.9790/0853-1709020111. （http://www.iosrjournals.org/iosr-jdms/papers/Vol17-issue9/Version2/A1709020111.pdf)

55. Sharma S. Gayatri mahavigyan - sanyukta sanskaran (Hindi). revised ed. Mathura, Uttar Pradesh, India: Yug Nirman Yojana Vistar Trust, Gayatri Tapobhumi; 2010. (http://literature.awgp.org/book/Super_Science_of_Gayatri/v2)

56. Saraswati SS. Asana Pranayama Mudra Bandha. Munger, Bihar, India: Yoga Publications Trust; 2006. 